\title{
Congress backs home for orphaned agencies
}

Washington. The Science Committee of the US House of Representatives has suggested that, if the Department of Commerce is abolished - as now seems likely - a new, independent agency should be set up to absorb the National Oceanic and Atmospheric Administration (NOAA) and the National Institute of Standards and Technology (NIST).

Proposals for such an agency, to be called the US Science and Technology Administration, were incorporated in a bill passed by the committee last week. They replace an earlier suggestion by new House Republicans led by Dick Chrysler (Michigan) to sell off the NOAA and NIST research laboratories, which absorb most of the two-thirds of the commerce department's \$4-billion annual budget spent on research, after the department's closure.

But the move was immediately criticized by Democrats as little more than a cosmetic reorganization aimed at winning credit for abolishing a governmental department without actually changing the federal government's role. "There is no evidence that abolishing the Department of Commerce, and creating this new bureaucratic superstructure, will save any money," says George Brown (Democrat, California), the senior minority member on the science committee and a strong critic of Republican plans.

Brown's interpretation gained credibility when Robert Walker (Republican, Pennsylvania), chairman of the committee, unexpectedly accepted an amendment removing from the bill a provision that would have capped spending on all functions of the Department of Commerce at 75 per cent of their 1994 levels. The successful amendment was put forward by Connie Morella (Republican, Maryland), who is keen to protect the main NIST laboratory at Gaithersburg, which is in her congressional district.

\section{Soros fund wins corporate support}

Moscow. For the first time since the fall of the communist regime, a prominent business organization has promised to provide substantial support for Russia's basic research.

At a press conference held in Moscow last week, Boris Saltykov, the minister of science and technology policy, announced that the Joint Stock Company LOGOVAZ is to make a grant of US\$1.5 million to the International Science Foundation (ISF), originally set up with financing from the Hungarian-born financier George Soros.

The new money will be used to extend into next year the ISF's Conference Travel Grants Program, which supports the participation of Russian researchers at international conferences. Salytkov's announcement was made in the presence of both Soros himself and of Boris Berezovsky, the president of LOGOVAZ.

Although the amount involved is not large, its main significance is the fact that it is the first time a Russian businessman has joined efforts to support Russian science, thus re-establishing a strong tradition of philanthropy that existed in pre-revolutionary Russia.

At the same time, Soros himself has said that he intends to continue financing the ISF programme which provides Russia's scientific community with access to leading Western science journals.

Meanwhile, the Presidium of the Russian Academy of Sciences (RAS) has devoted its first meeting of the new academic year to a discussion of the proposed law on science and the state scientific and technological policy which is currently before the State Duma, the

\section{Russian parliament.}

The academicians are opposed to the definition of the status of the academy proposed in the new bill, namely that it should be classified as a "state organization", meaning not only that it will be financed from the state budget, but also that the state, for this reason, has the right to control its activities, in particular by nominating its officials.

Members of the academy say that they do not object to the principle of state financing of their activities. But they want the academy to be a 'self-regulating' public organization, and to be able to elect its leaders and distribute the money it gets from the state as it wishes.

Vladimir Kudryavtsev, vice-president of the academy and a lawyer by profession, suggested that a new status should be created for the academy as a "state-public" body. This would have the advantage of being financed by the state while avoiding the unpleasant consequences that could follow.

Until now, the Russian Academy of Science has seldom failed in its struggle against the government to retain control of its activities, and many observers feel that it stands a good chance of winning the current dispute.

In a separate move, the Russian government has issued a decree stating that the financing of the Russian Humanities Scientific Fund (RHSF) is to be doubled, and that in future the fund will receive 1.0 per cent of the total budget allocated for scientific research every year, rather than the former humanities allocation of 0.5 per cent. Carl Levitin
But the idea of a new agency embracing the science functions of NOAA and NIST - a watered-down version, in effect, of Walker's earlier proposal for a far grander Department of Science (see Nature 374, $201 ; 1995)$ - is likely to survive when the House passes a bill to dismantle the commerce department.

The bill was approved by Walker's committee last week, after it had heard testimony on the future of the department earlier in the week from Ronald Brown, the commerce secretary, Barbara Franklin, his Republican predecessor, Chrysler, and 16 other witnesses.

Chrysler appeared to win few converts for his original proposal. He described the department as a "hall closet" — or cupboard - for the various bits and pieces which other government departments did not want. When asked by Vernon Ehlers (Republican, Michigan) whether he had such a cupboard at home, Chrysler replied, rather lamely, that he did, but that he also balanced his budget.

Calling for the privatization of the National Weather Service, Chrysler pointed out that "75 to 80 per cent of newspapers" already obtained their weather information from private sector sources. But committee members asked if he knew where the private sector obtained its data, underlining Chrysler's apparent lack of awareness that it is all provided by the weather service and is therefore supported by the government.

Brown clashed angrily with Franklin over a statement in her testimony that NIST had been "politicized" under its current director, Arati Prabhakar, and her claim that the way in which the Advanced Technology Programme (ATP) was now run "was the biggest part of that".

Challenged to produce specific evidence, Franklin, who supported ATP under the Bush administration, said she did not know what had been happening since she left office. "You don't like it because you're not in control of it any more," stormed Brown. He pointed out that Prabhakar was a career official, appointed on the basis of her impressive track record at ARPA, and admonished Franklin for "coming here to sloganize".

Three prominent Republican members - Morella, Sherwood Boehlert (New York) and Tom Davis (Virginia) - also supported a rescue of the ATP. Nevertheless, the bid was roundly defeated by the committee.

Other House committees are now considering the Department of Commerce Dismantling Act, which is likely either to be passed on its own by the House, or to be incorporated into a large 'reconciliation' bill at some point in the next few weeks (see Nature 377, 93; 1995). Colin Macilwain 